\title{
Canopy structure and morphogenesis of Italian ryegrass intercropped with red clover under cutting intervals determined by thermal sum
}

\author{
Fernando Ongaratto ${ }^{*}$ (i) Marta Gomes da Rocha ${ }^{2}$ (i) Luciana Pötter ${ }^{2}$ (i) Tuani Lopes Bergoli ${ }^{2}$ \\ Paula de Oliveira Severo ${ }^{2}$ (i) Juliana Squizani Dutra ${ }^{2}\left(\right.$ Juliana Missio Machado $^{2}$ () \\ Lisiani Rorato Dotto ${ }^{2}$ (i) Amanda Carneiro Martini ${ }^{(1)}$ Eduarda Proença de Oliveira ${ }^{2}$ (C)
}

${ }^{1}$ Departamento de Zootecnia, Faculdade de Ciências Agrárias e Veterinárias, Universidade Estadual Paulista "Júlio de Mesquita Filho" (Unesp), 14884-900, Jaboticabal, SP, Brasil. E-mail: fernandoongaratto@hotmail.com. *Corresponding author. ${ }^{2}$ Departamento de Zootecnia, Universidade Federal de Santa Maria (UFSM), Santa Maria, RS, Brasil.

ABSTRACT: The canopy structure and morphogenesis of ryegrass (Lolium multiflorum Lam.) was investigated after it was over seeded with Tifton 85 (Cynodon spp.) and intercropped with red clover (Trifolium pratense L.). Time intervals between cuts were determined by different thermal sums $(125,250,375$, and 500 degree-days [DD]). Cuts were conducted at a height equivalent to 50\% of the average canopy height. Morphogenic and structural data were collected from July to October of 2016 and 2017, from a completely randomized block experimental design. Canopy height, extended tiller height, pseudostem length, and forage mass were fitted to linear equations according to the thermal sums. Interaction of ryegrass with red clover was the highest (12.1\%) for longer cut intervals (375 and 500 DD). The leaf appearance rate $(0.0080$ leaf $/ D D)$, phyllochron value $(128.8 \mathrm{DD})$, and senescence rate $(0.10 \mathrm{~cm} / \mathrm{DD})$ of ryegrass were comparable between the different intervals. The slowest elongation rate $(0.06 \mathrm{~cm} / \mathrm{DD})$ with the shortest interval duration between cuts $(171.6 \mathrm{DD})$ was observed in the $125 \mathrm{DD}$ interval. According to the findings from this 2-year experiment, the use of a $250 \mathrm{DD}$ cut interval was recommended between grazing events, taking into account the efficiency of forage use, ryegrass leaf, stem ratio, and interactions with red clover in the canopy under rotational stocking.

Key words: Lolium multiflorum Lam., Overseeding, Rotational Stocking, Tifton 85, Trifolium pratense L.

Estrutura do dossel e morfogênese do azevém anual consorciado com trevo vermelho em intervalos de corte determinados por soma térmica

RESUMO: A estrutura do dossel e a morfogênese do azevém (Lolium multiflorum Lam.) foram investigadas após a sobressemeadura em Tifton 85 (Cynodon spp.) e consorciado com trevo vermelho (Trifolium pratense L.). Os intervalos de tempo entre os cortes foram determinados por diferentes somas térmicas (125, 250, 375 e 500 graus-dia [GD]). Os cortes foram realizados a uma altura equivalente a 50\% da altura média do dossel. Os dados morfogênicos e estruturais foram coletados no periodo de julho a outubro de 2016 e 2017 , em um delineamento experimental de blocos ao acaso. A altura do dossel, a altura estendida do perfilho, o comprimento do pseudocolmo e a massa de forragem se ajustaram a equações lineares de acordo com a soma térmica. A consorciação de azevém e trevo vermelho foi maior (12,1\%) para intervalos de corte mais longos (375 e $500 \mathrm{GD})$. A taxa de aparecimento foliar (0,0080 folha/GD), filocrono (128,8 GD) e a taxa de senescência (0,10 cm $/ G D)$ do azevém não foram diferentes entre os intervalos de corte. A menor taxa de elongação $(0,06 \mathrm{~cm} / G D)$ e duração de elongação (171,6 GD) foi observada no menor intervalo entre cortes, 125 GD. De acordo com os achados deste experimento de dois anos, recomenda-se o uso de um intervalo de corte de $250 \mathrm{GD}$ entre os eventos de pastejo, levando em consideração a eficiencia do uso de forragem, proporção de folhas e colmo de azevém e trevo vermelho no dossel, sob lotação rotativa.

Palavras-chave: Lolium multiflorum Lam., sobressemeadura, lotação rotativa, Tifton 85, Trifolium pratense L.

\section{INTRODUCTION}

In regions with a humid subtropical climate, the practice of over seeding annual coldseason grasses and legumes, such as Italian ryegrass (Lolium multiflorum Lam.) and red clover (Trifolium pratense L.) with warm-season perennial grasses like
Tifton 85 (Cynodon spp.) is performed. Appropriate management of intercropping different forage plant species provides an extended period for pasture utilization, and in the long term, the use of legumes allows reduced applications of nitrogen fertilizers; this has environmental and economic benefits (STEINFELD, 2006). 
Plant development processes are temperature-regulated and do not follow a human calendar. In subtropical climatic conditions, determining the intervals between grazing in livestock production systems that use rotational stocking is challenging, as there are considerable fluctuations in average daily temperatures, even within a single season. In these conditions, using the degree-day (DD) concept can be a useful tool in pasture management as it integrates a plant-relevant unit of time into a human one. However, adopting this management strategy depends on understanding the relationship between degree-days and forage morphogenic characteristics. According to CÂNDIDO et al. (2005), adequate interval durations between grazing favors the restoration of leaf area, increases light interception and forage production, and the replenishment of organic reserves. Very long time intervals between grazing can compromise the forage nutrient value, canopy structure, livestock performance, and forage intake. In Italian ryegrass, its phyllochron values have been used as a reference to determine the intervals between grazing by applying the thermal sums concept; examples of reported thermal sums are 312.5 degree-day (DD; CONFORTIN et al., 2010; MACHADO et al., 2011), 250 DD (ROSA et al., 2015) and 187.5 DD (STIVANIN et al., 2014; MOTERLE et al., 2017).

Simultaneous evaluation of different time intervals between cuts $(125,250,375$, and 500 DD) of Italian ryegrass intercropped with red clover and over seeded with Tifton 85 under similar environmental conditions (light, water, and nutrients) can aid in determining the management criteria for intercropping cut or grazed pastures. The objective of this study was to evaluate the effect of different time intervals between cuts on the canopy's structural characteristics, the botanical and structural interactions of the species in the forage mass, and ryegrass morphogenic characteristics and indicate a intervals between grazing, in degrees days, for the intercropping: ryegrass, red clover and tifton 85 .

\section{MATERIALS AND METHODS}

This experiment was carried out in Santa Maria, Brazil, from May 2016 to October 2017; coordinates $29^{\circ} 43^{\prime} \mathrm{S}, 53^{\circ} 42^{\prime} \mathrm{W}$, at an altitude of $95 \mathrm{~m}$ above sea level. The Köppen climate classification of the region is humid subtropical (Cfa). The soil in the experimental area $(0.8 \mathrm{ha})$ is classified as Paleudalf (SANTOS et al., 2013), a soil suborder of Alfisol. The mean soil chemical characteristic values in the experimental area were: $\mathrm{pH}-\mathrm{H}_{2} \mathrm{O}$ : 5.7; $\mathrm{pH}-\mathrm{SMP}$ : 5.9; clay: 22\%; P: $7.4 \mathrm{mg} \mathrm{L}^{-1}$; $\mathrm{K}: 0.166 \mathrm{mg} \mathrm{L}^{-1}$; OM: 2.6\%; $\mathrm{Al}^{3+}: 0$ cmolc L ${ }^{-1} ; \mathrm{Ca}^{2+}: 4.3$ cmolc dm${ }^{3} ; \mathrm{Mg}^{2+}$ : 2.0 cmolc $\mathrm{L}^{-1}$; effective CEC: $10.2 \mathrm{cmolc}^{3}$; base saturation: $58 \%$; and $\mathrm{Al}$ saturation: $0 \%$. Fertilizer treatment used was NPK 5-20-20, according to the fertilization and timing recommendations for Rio Grande do Sul and Santa Catarina States (CQFS-RS/ $\mathrm{SC}, 2016)$ ), and three urea applications at similar amounts, totaling $55 \mathrm{~kg}$ of $\mathrm{N} \mathrm{ha}^{-1}$, per harvest cycle.

Tifton 85 (Cynodon spp.) was established in the experimental area in 2013. May 2016, annual red clover [(Trifolium pratense L.) cv. Estanzuela 116] with Italian ryegrass [(Lolium multiflorum Lam) cv. Comum] were established through overseeding after the pasture had been mowed; $8 \mathrm{~kg}$ of seed $\mathrm{ha}^{-1}$ of red clover and $45 \mathrm{~kg}$ of seed $\mathrm{ha}^{-1}$ of ryegrass were used. The red clover seeds were inoculated and pelleted with Rhizobium leguminosarum bv. trifolii before overseeding. From April to June of 2017, only Italian ryegrass was established by overseeding with Tifton 85 . The test site was divided into plots $(4 \times$ $4 \mathrm{~m})$, with 4 replicates per different time intervals between cuts at 125, 250, 375, and 500 DD from July 2016 to October 2017. From October 2016 to April 2017, an interval of 242 DD between cuts was applied for all of the plots. The accumulated thermal sum (TS) value for each interval was calculated using the following formula:

$\mathrm{TS}=\left\{\left[\left(\mathrm{T}^{\circ} \mathrm{Mx}+\mathrm{T}^{\circ} \mathrm{Mn}\right) / 2\right]-\mathrm{BT}\right\}$, where $\mathrm{T}^{\circ} \mathrm{Mx}$ is the daily maximum temperature $\left({ }^{\circ} \mathrm{C}\right) ; \mathrm{T}^{\circ} \mathrm{Mn}$ is the daily minimum temperature $\left({ }^{\circ} \mathrm{C}\right)$, and $\mathrm{BT}$ is the basal temperature; $5{ }^{\circ} \mathrm{C}$ for cold season grasses and $10{ }^{\circ} \mathrm{C}$ for warm season grasses (COOPER and TAINTON, 1968). The temperature data were collected at the National Institute of Meteorology (INMET), $800 \mathrm{~m}$ from the experimental site.

The sum of the average daily temperatures in determining the different DD intervals between cuts started on July 19, 2016, and July 13, 2017. A standardized cut was made $10 \mathrm{~cm}$ above the ground to determine the pre-cut forage mass values; $1800 \mathrm{~kg}$ $\mathrm{ha}^{-1}$ dry matter (DM) in 2016 and $2000 \mathrm{~kg} \mathrm{ha}^{-1} \mathrm{DM}$ in 2017. The canopy height was measured using a graduated ruler, doing a systemic walk, at 20 points per plot on the dates corresponding to the target TS value for each respective plot. Cutting in each plot was conducted at the height equivalent to $50 \%$ of the average canopy height.

To estimate forage mass, and botanical and structural composition per plot from the tested site, cuts were made as close to the ground using a $0.25 \mathrm{~m}^{2}$ frame at two areas representative of the 
average canopy height. Fresh forage samples were weighed and weighed again after drying in an oven with forced-air circulation at $55{ }^{\circ} \mathrm{C}$ for $72 \mathrm{~h}$; the forage mass was calculated based on weight in $\mathrm{kg}$ $\mathrm{DM} \mathrm{ha}{ }^{-1}$. To determine the botanical and structural composition, the leaves, stems (culm + leaf sheath) of ryegrass and Tifton 85 , ryegrass inflorescence, and red clover (leaves + stem), as well as other species and dead organic materials were manually separated from the forage samples obtained. From these samples, the percentage of interaction between species and the mass of each sampled component were calculated as $\mathrm{kg} \mathrm{DM} \mathrm{ha}{ }^{-1}$. Ten ryegrass tillers were collected to determine the tiller dry weight $(\mathrm{g})$ when the TS value of the respective plot had been reached. Tillers were weighed and dried at $55^{\circ} \mathrm{C}$ for $72 \mathrm{~h}$ in an oven with forced-air circulation.

An area was marked using wooden stakes to represent the canopy, and ryegrass tillers (24/plot) were identified with colored plastic rings (CARRÈRE et al., 1997). Tiller measurements were performed twice a week, comprising of the height of the pseudostem $(\mathrm{cm})$ and extended tiller $(\mathrm{cm})$, as well as the lengths $(\mathrm{cm})$ of expanded, expanding, and senescent leaves. Expanded leaves were measured from their ligule, while expanding leaves were measured from the ligule of the last expanded leaf. In senescent leaves, only the green portion of the leaf blade was measured (only leaves with a maximum of $50 \%$ senescence were considered). The pseudostem height was measured from the ground to the height of the ligule of the last expanded leaf. The extended tiller height, being the height from ground to the tip of the last green leaf, was only measured in 2017.

The total number of ryegrass leaves, and the number of live leaves per tiller derived from the number of expanding, expanded, and senescent leaves. Leaf appearance rate (leaf/degree-day [DD]) of the ryegrass was determined as the ratio between the number of leaves produced and TS value of the evaluated interval. The phyllochron value (based on DDs) was calculated as the inverse of the appearance rate. The leaf life span (based on DDs) was calculated using the average number of green leaves per tiller and the average phyllochron value. The duration of leaf elongation (based on DDs) was calculated using the average number of expanding leaves and the average phyllochron value. Elongation (cm/DD) and senescence $(\mathrm{cm} / \mathrm{DD})$ rates of ryegrass leaf blades were calculated as the ratio of the average elongation or senescence of the leaf between two consecutive evaluations, and the TS value of the cutting interval (CONFORTIN et al., 2010).
A randomized complete block design was used; the blocking criterion was soil topography, with four different time intervals between cuts (thermal sum) and four replicates per interval plot. The experiment was carried out for two consecutive years. $\mathrm{Y}_{\mathrm{ijk}}=\mu+\mathrm{b}_{\mathrm{i}}+\mathrm{T}_{\mathrm{j}}+\mathrm{e}_{\mathrm{j}: \mathrm{k}}+\mathrm{k}_{\mathrm{ijkl}}$

Where $\mu=$ overall mean; $b_{i}=$ random effect of blocks; $\mathrm{Tj}=$ fixed effect of the different intervals; $e_{j}: k=$ nested random effect per plot of the different intervals; $\mathrm{k}_{\mathrm{ij} \mathrm{l}}=$ random error in the experiment. Analysis of variance (ANOVA) was used to analyze the data. When the variables presented normality, the mixed procedure of $\mathrm{SAS}^{\circledR}$ was used, taking into account the fixed effect of the different cutting intervals (TS) and the random effects of the residue, the blocks, and the years. A test for selection of covariance structures was performed using the Bayesian information criterion (BIC) to determine the model that best represented the data. Variable responses were modeled according to TS value, using polynomial function to the third order. In the regression analysis, the selected model was based on the significance of the linear, quadratic and cubic coefficients, using the Student's $t$-test at $10 \%$ probability. When not fitted to regression models, the averages were compared using the 'lsmeans' procedure $(5 \%)$. The variables were also subjected to Pearson's linear correlation.

\section{RESULTS}

The mean temperature and cumulative rainfall values were $16.6^{\circ} \mathrm{C}$ with $130.7 \mathrm{~mm}$, and 18.4 ${ }^{\circ} \mathrm{C}$ with $102.2 \mathrm{~mm}$ for 2016 and 2017 , respectively (Table 1). Environmental conditions did not limit forage development.

Data on canopy height, ryegrass tillers, and forage mass was collected for a thermal sum of 1125 degree-day (DD) over a two year experimental period. During this period, nine, four, three, and two cuts were performed in the $125,250,375$, and 500 DD intervals, respectively. On average, the cuts were made every $7.4,14.9,22.4$, and 29.2 days for the 125 , 250, 375, and 500 DD intervals, respectively.

Canopy height, forage mass, ryegrass tiller mass, ryegrass leaf mass, and ryegrass stem mass were fitted to increasing linear equations as a function of the TS value. Equations obtained were: canopy height $\left(\hat{\mathrm{Y}}=4.10+0.077 \mathrm{x} ; P=0.0001 ; \mathrm{r}^{2}=\right.$ $0.82)$; forage mass $\left(\hat{\mathrm{Y}}=746.9+5.2 \mathrm{x} ; P=0.0001 ; \mathrm{r}^{2}=\right.$ $0.72)$; ryegrass tiller weight $(\hat{\mathrm{Y}}=0.047+0.0004 \mathrm{x} ; P$ $\left.=0.0007 ; \mathrm{r}^{2}=0.30\right) ;$ ryegrass leaf mass $(\hat{\mathrm{Y}}=449.93+$ $\left.0.58 \mathrm{x} ; P=0.0001 ; \mathrm{r}^{2}=0.34\right)$; and ryegrass stem mass

Ciência Rural, v.50, n.11, 2020. 
Table 1 - Average temperature and cumulative rainfall for years 2016 and 2017 and historical average values.

\begin{tabular}{|c|c|c|c|c|c|}
\hline & & July & August & September & October \\
\hline \multirow{3}{*}{ Average temperature $\left({ }^{\circ} \mathrm{C}\right)$} & 2016 & 14.94 & 17.08 & 15.60 & 18.65 \\
\hline & 2017 & 16.27 & 16.70 & 19.77 & 21.07 \\
\hline & Historical & 13.41 & 14.00 & 16.02 & 18.51 \\
\hline \multirow{3}{*}{ Cumulative rainfall (mm) } & 2016 & 10.60 & 123.20 & 53.00 & 336.20 \\
\hline & 2017 & 5.70 & 246.50 & 131.50 & 25.00 \\
\hline & Historical & 81.80 & 132.66 & 73.50 & 144.00 \\
\hline
\end{tabular}

Source: National Institute of Meteorology (INMET).

$\left(\hat{\mathrm{Y}}=47.83+1.52 \mathrm{x} ; P=0.0001 ; \mathrm{r}^{2}=0.45\right)$. Therefore, a 1 DD increase in the TS value is expected to cause increases in canopy height by $+0.077 \mathrm{~cm},+5.2 \mathrm{~kg}$ $\mathrm{DM} \mathrm{ha}^{-1}$ in forage mass, $+0.0004 \mathrm{~g}$ in tiller weight, $+0.58 \mathrm{~kg} \mathrm{DM} \mathrm{ha}^{-1}$ in ryegrass leaf mass, and $+1.52 \mathrm{~kg}$ $\mathrm{DM} \mathrm{ha}^{-1}$ in ryegrass stem mass.

The ryegrass leaf : stem ratio did not fit any regression equation but was greater in the 125 DD cut interval, and lower in the 375 and 500 DD intervals that did not differ from each other, and an intermediate value for the 250 DD interval (Table 2). Percentage of ryegrass inflorescence was different for all cut intervals, with a higher species interaction in the $500 \mathrm{DD}$ interval, and a lower interaction in the 125 DD interval (Table 2).

The percentage of species interaction between the ryegrass and Tifton 85 was the highest in the 125 DD interval (Table 2), and presented similar results in the other cut intervals $(6.92 \%)$. Interaction between the ryegrass with red clover was the highest $(12.09 \%)$ in the 375 and 500 DD cut intervals, with a comparable value in the $250 \mathrm{DD}$ interval, and the lowest percentage was reported in the $125 \mathrm{DD}$ interval (Table 2). The interaction percentage of other species $(1.46 \% \pm 0.71)$ in the canopy was similar for all cut intervals. Interaction with dead organic material was highest in the 125 DD cut interval, with intermediate interactions observed in the 250 and 375 DD intervals, and a smaller interaction in the 500 DD interval (Table 2).

During the data collection for morphogenic and structural variables (pseudostem length, extended tiller height, and number of elongating, expanded, senescent, live, and total leaves), the thermal sum was 750 DD (combining 2016 and 2017 data), as the data collection was suspended when more than $50 \%$ of the ryegrass tillers entered the reproductive stage. Prior, six, three, two, and one canopy cuts were performed for the $125,250,375$, and $500 \mathrm{DD}$ intervals, respectively.

Numbers of elongating, expanded, live, and total ryegrass leaves were fitted to linear decreasing equations according to the degree-day used in the interval between cuts: number (n) of elongating leaves $\left(\hat{\mathrm{Y}}=1.45-0.0006 \mathrm{x} ; P=0.0002 ; \mathrm{r}^{2}=0.37\right)$; number of expanded leaves $(\hat{\mathrm{Y}}=2.48-0.0011 \mathrm{x} ; P=$ $\left.0.0001 ; \mathrm{r}^{2}=0.39\right)$; number of live leaves $(\hat{\mathrm{Y}}=3.93-$ $\left.0.0018 \mathrm{x} ; P=0.0001 ; \mathrm{r}^{2}=0.50\right)$; and total number of leaves $\left(\hat{\mathrm{Y}}=4.47-0.0015 \mathrm{x} ; P=0.0001 ; \mathrm{r}^{2}=0.42\right)$. Where $1 \mathrm{DD}$ increase in the TS value following a cut interval is expected to decrease the number of elongating leaves by $-0.0006 \%,-0.0011 \%$ in the number of expanded leaves, $-0.0018 \%$ in the number of live leaves, and $-0.0015 \%$ in the total number of leaves. The TS values used to determine the interval between cuts did not significantly affect the number of senescent leaves $(0.63 \pm 0.06$ leaves $)$.

The leaf appearance rate $(0.008 \pm 0.0003$ leaf/DD), phyllochron value (128.84 $\pm 5.18 \mathrm{DD})$, and senescence rate $(0.010 \pm 0.01 \mathrm{~cm} / \mathrm{DD})$ were similar for all intervals between cuts. The fastest leaf elongation rate $(0.1084 \pm 0.03 \mathrm{~cm} / \mathrm{DD})$ was observed for the 250,375 , and 500 DD intervals, which did not differ from each other, and the slowest rate was recorded for the $125 \mathrm{DD}$ interval (Table 3). The greatest leaf life span was reported for the 125 DD interval, and the lowest in the 500 DD interval, and intermediate leaf life spans in the other intervals (Table 3). The maximum foliar elongation was observed in the 125 DD interval (Table 3) and was similar for the other thermal sums $(158.33 \pm 5.40 \mathrm{~cm} / \mathrm{DD})$.

The extended tiller height of ryegrass was fitted to an increasing linear equation as a function of degree-day $\left(\hat{\mathrm{Y}}=12.15+0.021 \mathrm{x} ; P=0.0001 ; \mathrm{r}^{2}=\right.$ 0.72 ), where an increase of $0.021 \mathrm{~cm}$ in tiller height is expected with a $1 \mathrm{DD}$ increase in the TS value. The 
Canopy structure and morphogenesis of Italian ryegrass intercropped with red clover under cutting intervals determined by thermal sum. 5

Table 2 - Leaf:stem ratio of ryegrass (L:S), percentage participation in the canopy of ryegrass inflorescence, Tifton 85, red clover, other species and dead material under different cutting intervals (during years 2016 and 2017).

\begin{tabular}{|c|c|c|c|c|c|c|}
\hline \multirow[t]{2}{*}{ Variables } & \multicolumn{6}{|c|}{-----------------------------------------------Cutting intervals ${ }^{\dagger}-\mathrm{-}$} \\
\hline & 125 & 250 & 375 & 500 & SEM $^{*}$ & $\mathrm{P}^{* *}$ \\
\hline $\mathrm{L}: \mathrm{S}$ & $2.60^{\mathrm{a}}$ & $1.58^{\mathrm{b}}$ & $0.97^{\mathrm{c}}$ & $0.73^{\mathrm{c}}$ & 0.18 & 0.0001 \\
\hline Inflorescence & $0.84^{\mathrm{d}}$ & $3.72^{\mathrm{c}}$ & $9.76^{\mathrm{b}}$ & $12.09^{\mathrm{a}}$ & 0.73 & 0.0001 \\
\hline Tifton $85^{\ddagger}$ & $13.54^{\mathrm{a}}$ & $7.76^{\mathrm{b}}$ & $7.54^{\mathrm{b}}$ & $5.48^{\mathrm{b}}$ & 1.89 & 0.0001 \\
\hline Red Clover ${ }^{\ddagger}$ & $8.59^{\mathrm{b}}$ & $10.60^{\mathrm{ab}}$ & $11.52^{\mathrm{a}}$ & $12.66^{\mathrm{a}}$ & 9.33 & 0.0121 \\
\hline Other $s p p^{\ddagger}$ & 1.88 & 1.01 & 1.64 & 1.31 & 0.71 & 0.5776 \\
\hline Dead material $^{\ddagger}$ & $29.62^{\mathrm{a}}$ & $20.12^{b}$ & $18.62^{\mathrm{bc}}$ & $15.75^{\mathrm{c}}$ & 6.02 & 0.0001 \\
\hline
\end{tabular}

${ }^{\dagger}$ degree-day, ${ }^{\ddagger} \%$. ${ }^{*}$ Standard error of the mean; ${ }^{* *}$ probability between treatments; different letters in the same row indicate significantly different mean values by lsmeans test $(\mathrm{P}<0.05)$.

pseudostem height is explained by the equation ( $\hat{Y}$ $\left.=4.172+0.0011 \mathrm{x} ; P=0.0001 ; \mathrm{r}^{2}=0.53\right)$, and a 1 DD increase is expected to increase the pseudostem height by $0.0011 \mathrm{~cm}$.

\section{DISCUSSION}

Slightly defoliated canopies form higher canopies with less light penetration at the base; and therefore, less tillering (GUY et al., 2018). Old and thick tillers increase forage, which results in more leaves and greater ryegrass stem mass $\left(\mathrm{kg} \mathrm{DM} \mathrm{ha}{ }^{-1}\right)$. Canopy height invariably lead to a concomitant reduction in the leaf: stem ratio per tiller as the diameter of the stem increases to support the weight of an organ (leaves, in this case) (SBRISSIA and DA SILVA, 2008). Greater forage mass and higher canopies, like in the 500 DD cut interval, reduces the possibility of decapitation and death of tillers during cutting, which consequently increases the probability of tillers becoming reproductive (BARBOSA et al., 2008). The percentage of ryegrass inflorescences showed a high and positive correlation with the canopy height $\left(\mathrm{r}^{2}=0.82 ; P=0.02\right)$ in the 250 and $500 \mathrm{DD}$ cut intervals. For ryegrass, re-semination is required and should occur for the longest interval between cuts due to the greater production of inflorescences.

Forage accumulation in Tifton 85 was reduced during the cold season and early spring, and it was shaded by ryegrass and red clover for the intervals above $125 \mathrm{DD}$, which reduced its interaction with the canopy. In the 125 DD interval, frequent defoliation allowed for greater luminosity at the base of the canopy, and likely also reduced the organic reserves for the cold season forage species, in response to the low leaf area index, and promoting the interaction between warm season species in the canopy. Red clover does not support intense grazing and becomes dominated by other components of the canopy when subjected to frequent cutting (TRACY et al., 2014), which was observed in the 125 DD interval. A high and positive correlation for ryegrass existed according to the percentage of species interaction with red clover and canopy height in all the cut interval, except for $125 \mathrm{DD}(250,375$, and 500 $\mathrm{DD} ; \mathrm{r}=0.83 ; \mathrm{P}=0.019$ ).

The other species recorded included Briza subaristata, Cynodon dactylon cv. Comum, Cyperus spp., Elephantopus mollis, Eragrostis plana, Hydrocotyle spp., Richardia brasiliensis, Oxalis spp., and Soliva pterosperma. In the long term, despite the low interaction of the other species, management with frequent defoliation is expected to result in a gradual reduction of the productive capacity and vigor of the forage plants. This may facilitate the emergence and development of weeds or other undesirable plants, resulting in zootechnical indices below the potential capacity of the area (TRACY et al., 2004).

In a subtropical climate, formation of new foliar tissues in Tifton 85 is low from July to October, with a high senescence of the existing material. Therefore, the greater interaction of this species with ryegrass in the $125 \mathrm{DD}$ cut interval also resulted in a greater contribution of dead organic material. From July to December, different species of Cynodon contributed a high percentage of stems $(40.7 \%)$ and dead organic material $(41.5 \%)$, compared to leaves (17.6\%; FAGUNDES et al., 1999).

Although, the number of leaves is genetically determined (LEMAIRE and CHAPMAN, 1996), it can also be influenced by climatic and management conditions (PATÊS et al., 2007).

Ciência Rural, v.50, n.11, 2020. 
Table 3 - Morphogenic characteristics, duration of elongation and senescence rate of ryegrass under different cutting intervals (during years 2016 and 2017).

\begin{tabular}{|c|c|c|c|c|c|c|}
\hline \multirow[t]{2}{*}{ Variables } & \multicolumn{6}{|c|}{-Cutting invervals ${ }^{\dagger}$} \\
\hline & 125 & 250 & 375 & 500 & SEM $^{*}$ & $\mathrm{P}^{* *}$ \\
\hline $\mathrm{TxA}^{\ddagger}$ & 0.0084 & 0.0080 & 0.0080 & 0.0078 & 0.0003 & 0.4260 \\
\hline $\mathrm{F}^{\dagger}$ & 122.70 & 129.46 & 132.10 & 131.10 & 5.17 & 0.4041 \\
\hline $\mathrm{TxE}^{\S}$ & $0.0628^{b}$ & $0.0909^{\mathrm{a}}$ & $0.1108^{a}$ & $0.1236^{\mathrm{a}}$ & 0.03 & 0.0421 \\
\hline $\mathrm{DVF}^{\dagger}$ & $463.92^{\mathrm{a}}$ & $415.15^{\mathrm{c}}$ & $427.47^{\mathrm{b}}$ & $410.38^{d}$ & 14.04 & 0.0037 \\
\hline $\mathrm{DE}^{\dagger}$ & $171.59^{\mathrm{a}}$ & $153.75^{\mathrm{b}}$ & $164.18^{b}$ & $157.06^{\mathrm{b}}$ & 5.39 & 0.0383 \\
\hline $\mathrm{TxS}^{\S}$ & 0.0777 & 0.1219 & 0.1010 & 0.0881 & 0.01 & 0.0700 \\
\hline
\end{tabular}

${ }^{\dagger}$ Degree-day; ${ }^{\dagger} \mathrm{TxA}$ (appearance rate; leaf/degree-day), ${ }^{\dagger} \mathrm{F}$ (phyllochron; degree-day); ${ }^{\S} \mathrm{TxE}$ (elongation rate; cm degree-day); ${ }^{\dagger} \mathrm{DVF}$ (Leaf life span; degree-day); $\mathrm{DE}$ (elongation duration; degree-day) ${ }^{\S} \mathrm{TxS}$ (senescence rate; cm degree-day). ${ }^{*}$ Standard error of the mean; probability between treatments; different letters in the same row indicate significantly different mean values by lsmeans test $(\mathrm{P}<0.05)$

Changes in leaf number were observed according to the interval between cuts; the number of elongating, expanded, live, and total leaves decreased as the interval between cuts increased. This plastic response to defoliation intensity in Italian ryegrass may correspond to a grazing tolerance mechanism (BRISKE, 1996).

In our study, the cutting intensity did not modify the number of senescent leaves as they were localized to the lower part of the canopy. However, different values have been recorded for the number of senescent ryegrass leaves when three intensities of forage mass removal were used, with the highest number of leaves senescing at the lowest intensity $(21.1 \%$ forage mass removal; CONFORTIN et al., 2010).

The leaf appearance rate is genetically determined (LEMAIRE and CHAPMAN, 1996) to be relatively constant based on thermal time (degreeday). The phyllochron value is calculated as the inverse of the leaf appearance rate (PEREIRA et al., 2011) and is also relatively constant for a given genotype during tiller vegetative development (PAIVA et al., 2012). Leaf senescence is strongly influenced by gene expression (TAIZ et al., 2017), and regardless of the interval between cuts, the senescence rate of the ryegrass leaves was constant.

Frequent defoliation, as that which had occurred in the $125 \mathrm{DD}$ interval, leads to a considerable reduction in the leaf expansion rate due to the low mobilization of nitrogen and carbon reserves (SCHNYDER et al., 2000). After defoliation, the elongation rate of the ryegrass leaf was reduced by $70 \%$ (PONTES et al., 2003). In the canopies under a longer interval of defoliation, nutrients (mainly carbon and nitrogen) accumulate and can be directed to the expanding leaves that require higher levels of nutrients for tissue growth (LEMAIRE and AGNUSDEI, 2000).

The forage use efficiency would be optimized if the interval between cuts is less than the average life span of the leaves, and this occurred when the TS value was $125 \mathrm{DD}$, with 3.71 defoliations during the leaf life span. If the interval between cuts exceeds the life span of the leaves, as that which had occurred in the 500 DD interval $(0.82$ defoliations), then the forage use efficiency decreases (GASTAL and LEMAIRE, 2015). The appearance rate is the most stable morphogenic variable and should be used as a management criterion in ryegrass pastures. In contrast, leaf life span varies based on different cutting intervals, hence this parameter should not be considered as a criterion for managing rotational stocking.

The longest elongation duration, which was observed in the shortest cut interval, can be explained by the comparable phyllochron values for all cut intervals, and a reduction in the number of elongating leaves with increasing TS values. Leaf elongation occurs until the exteriorization of the ligule, after which a fully expanded adult leaf blade is present (DALE, 1982).

Lower pseudostem and extended tiller heights may be a morphological adaptation to more frequent and intense cutting, via a tolerance mechanism (BRISKE, 1996). A canopy with less frequent defoliation results in increased pseudostem and extended tiller heights. DAVIES et al. (1989) stated that the greater the height of the pseudostem, the longer the cell multiplication phase; and consequently, the longer the final length of the leaf blade and extended tiller (DURU and DUCROCQ, 2000). 


\section{CONCLUSION}

Under rotational stocking, the 250 DD cut interval was recommended based on the findings, taking into account the morphogenic characteristics of ryegrass and structural characteristics of the intercrop with Tifton 85 , ryegrass, and red clover. The desirable characteristics of the canopy structure was optimized at this interval, such as the interactions with red clover, ryegrass leaf: stem ratio, and the efficiency of forage use. By relating the recommended interval (250 DD) to the morphogenic characteristics of ryegrass, the values are equivalent to 1.9 for phyllochron and 0.6 for leaf life span.

\section{ACKNOWLEDGEMENTS}

The authors would like to thank Coordenação de Aperfeiçoamento de Pessoal de Nível Superior (CAPES) and Professor Dennis Poppi, University of Queensland, for reading the paper.

\section{DECLARATION OF CONFLICT OF INTERESTS}

The authors declare no conflict of interest. The founding sponsors had no role in the design of the study; in the collection, analyses, or interpretation of data; in the writing of the manuscript, and in the decision to publish the results.

\section{AUTHORS' CONTRIBUTIONS}

Fernando Ongaratto, Marta Gomes da Rocha, Luciana Pötter, Tuani Lopes Bergoli and Paula de Oliveira Severo conceived and designed experiments. Juliana Squizani Dutra, Juliana Missio Machado, Lisiani Rorato Dotto, Amanda Carneiro, Eduarda Proença de Oliveira Martini performed the experiments. All authors critically revised the manuscript and approved of the final version.

\section{REFERENCES}

BARBOSA, C. M. P. et al. Effect of grazing methods and intensities on annual ryegrass under natural reseedling. ACTA, v.30, n4, p.387-393, 2008. Available from: $<$ https://www.redalyc. org/pdf/3031/303126494002.pdf. >. Accessed: Apr. 09, 2019. doi: 10.4025/actascianimsci.v30i4.6463

BRISKE, D. D., Strategies of plant survival in grazed systems: a functional interpretation. In: HODGSON, J. and ILLIUS, A.W. The ecology and management of grazing systems. New York: CAB International, 1996. cap. 2, p. 37-67.

CÂNDIDO, M. J. D. et al. Morphophysiology of Panicum maximum cv. Mombaça canopy under intermittent stocking grazing of three rest periods. Revista Brasileira de Zootecnia, v.34, n.2, p.406-415, apr 2005. Available from: <http://www. scielo.br/pdf/\%0D/rbz/v34n2/25451.pdf>. Accessed: Sep. 24, 2019. doi: 10.1590/S1516-35982005000200007.

CARRÈRE, P. et al. Tissue turnover within grass-clover mixed swards grazed by sheep. Methodology for calculating growth, senescence and intake fluxes. Journal of Applied Ecology, v.34, n., p.333-348, apr. 2007. Available from: <https://www.jstor.org/ stable $/ 2404880$ ?seq=1\#metadata_info_tab_contents $>$. Accessed: Dec. 07, 2019. doi: $10.2307 / 240 \overline{4} 880$.

CONFORTIN, A. C. C. et al. Morphogenesis and structure of Italian ryegrass submitted to three grazing intensities. Morphogenetic. ACTA, v.32, n.4, p.385-391, 2010. Available from: <http://periodicos.uem.br/ojs/index.php/ActaSciAnimSci/ article/view/8657/8657>. Accessed: Jul. 03, 2019. doi: 10.4025/ actascianimsci.v32i4.8657.

COOPER, J. P. and TAINTON, N. M. Light and temperature requirements for the growth of tropical and temperate grasses. Herbage Abstracts, v.38, n.3, p.167-176, setp. 1968. Available from: \ttps://www.semanticscholar.org/paper/Lightand-temperature-requirements-for-the-growth-Cooper-Tainton/ fc9f13d6215d3fba92aafb0645dfa2b32cf22e8b>. Accessed: Mar. 27, 2019.

DALE, J. E. Some effects of temperature and irradiance on growth of the first four leaves of wheat, Triticum aestivum. Annals of Botany, v.50, n.6, p.851-858, dec. 1982. Available from: <https://academic.oup.com/aob/articleabstract/50/6/851/161190>. Accessed: Feb. 12, 2019. doi: 10.1093/oxfordjournals.aob.a086428.

DAVIES, D. A. Frequency of stocking rate required on contrasting upland perennial ryegrass pastures continuously grazed to a sward height criterion from May to July. Grass and Forage Science, v.44, p.213-221, 1989. Available from: < https://onlinelibrary.wiley.com/ doi/abs/10.1111/j.1365-2494.1989.tb01929.x>. Accessed: Mar. 26, 2019. doi: 10.1111/j.1365-2494.1989.tb01929.x.

DURU, M.; DUCROCQ, H. Growth and senescence of the successive grass leaves on a tiller ontogenic development and effect of temperature. Annals of Botany, v.85, n.5, p.635-643, May 2000. Available from: <https://academic.oup.com/aob/ article/85/5/635/2588177>. Accessed: Mar. 26, 2019. doi: 10.1006/ anbo.2000.1116.

SANTOS, H. G., et al. Sistema brasileiro de classificação de solos. Rio de Janeiro: Embrapa, 2013. 3 ed.

FAGUNDES, J. L. et al. Grazing intensities and the morphological composition of Cyonodon spp. pastures. Scientia Agricola, v.56, n.4, p.897-908, Aug. 1999. Available from: <http://www.scielo.br/ scielo.php?script $=$ sci arttext\&pid=S0103-90161999000400017 $>$. Accessed: May, 05, 2019. doi: 10.1590/S0103-90161999000400017.

GASTAL, F.; LEMAIRE, G. Defoliation, shoot plasticity, sward structure and herbage utilization in pasture: Review of the underlying ecophysiological processes. Agriculture, v.5, n.4, p.1146-117, 2015. Available from: <https://www.mdpi.com/20770472/5/4/1146>. Accessed: May, 13, 2019. doi: 10.3390/ agriculture 5041146 .

GUY, C. et al. Growth, morphology and biological nitrogen fixation potential of perennial ryegrass-white clover swards throughout the grazing season. The Journal of Agricultural Science, v.156, n.2, p-188-199, mar. 2018. Available from: <https://www.cambridge. org/core/journals/journal-of-agricultural-science/article/growthmorphology-and-biological-nitrogen-fixation-potential-ofperennial-ryegrasswhite-clover-swards-throughout-the-grazingseason/C7A42DA39D276D9C0CD2C456706A92F2>. Accessed: Dec. 02, 2019. doi: 10.1017/S0021859618000199. 
LEMAIRE, G.; CHAPMAN, D. Tissue flows in grazed plant communities. In: HODGSON, J. and ILLIUS, A.W., The ecology and management of grazing systems, New York: CAB International, 1996. Cap.1, p.3-36.

LEMAIRE, G.; AGNUSDEI, M. Leaf tissue turnover and efficiency of herbage utilization. In: LEMAIRE, G.; et al. Grassland ecophysiology and grazing ecology, Oxford: CABI International, 2000. Cap.14, p.279-302.

MACHADO, J. M. et al. Intensidade e frequência de desfolhação em azevém. Revista Brasileira de Agrociência, v.17, n.3, p.365374, 2011. Available from: <https://periodicos.ufpel.edu.br/ojs2/ index.php/CAST/article/view/2070>. Accessed: Mar. 27, 2019.

MOTERLE, P. H. et al. Displacement patterns of beef heifers receiving supplement in Italian ryegrass pasture. Arquivo Brasileiro de Medicina Veterinária e Zootecnia, v.69, n.4, p.1021-1029, 2017. Available from: <http://www.scielo.br/scielo. php?script $=$ sci_abstract\&pid=S0102-09352017000401021\&ln 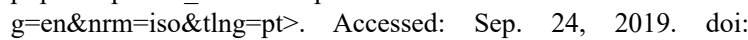 $10.1590 / 1678-4162-9258$.

PAIVA. A. J. et al. Structural characteristics of tiller age categories of continuously stocked marandu palisade grass swards fertilized with nitrogen. Revista Brasileira de Zootecnia, v.41, n.1, p.24-29, 2012. Available from: <http://www.scielo. br/scielo.php?pid $=$ S1516-35982012000100004\&script $=$ sci abstract>. Accessed: Apr. 09, 2019. doi: 10.1590/S151635982012000100004

PATÊS, N. M. DA S. et al. Morphogenetic and structural characteristics of tanzaniagrass submited to phosphorus and nitrogen fertilization. Revista Brasileira de Zootecnia, v.36, n.6, p.1736-1741, 2007. Available from: <http://www.scielo.br/scielo. php?script=sci_abstract\&pid=S1516-35982007000800005\&lng $=$ en $\& n r m=$ iso \&tlng $=p t>$. Accessed: Mar. 27, 2019. doi: 10.1590/ S1516-35982007000800005.

PEREIRA, O. G. et al. Morphogenic and structural characteristics of tifton 85 bermudagrass under different nitrogen doses and harvesting Heights. Revista Brasileira de Zootecnia, v.40, n.9, p.1870-1878, sept. 2011. Available from: $<$ http://www.scielo.br/scielo.php?script $=$ sci_arttext\&pid $=$ S1516-35982011000900005 $>$. Accessed: Dec. 27, 2019. doi: 10.1590/S1516-35982011000900005.

PONTES, L. S. et al. Morphogenetic and structural traits of ryegrass (Lolium multiflorum Lam.) managed under different sward heights. Revista Brasileira de Zootecnia, v.32, n.4, p.814-820, 2003. Available from: <http://www.scielo.br/scielo.php?pid=S1516- 35982003000400005\&script $=$ sci_abstract\&tlng=pt $>$. Accessed: Apr. 05, 2019. doi: 10.1590/S1516-35982003000400005.

COMISSÃO DE QUÍMICA E FERTILIDADE DO SOLO - CQFS - RS/SC. Manual de calagem e adubação para os Estados do Rio Grande do Sul e de Santa Catarina. 11 ed. Porto Alegre: SBCS - Núcleo Regional Sul, Pallotti, Santa Maria.

ROSA, A. T. N. et al. Methods to determine forage intake by lambs on Italian ryegrass. ACTA, v.37, n.4, p.365-371, oct-dec, 2015. Available from: <http://periodicos.uem.br/ojs/index.php/ ActaSciAnimSci/article/view/28051/pdf_114>. Accessed: Mar. 18, 2019. doi: 10.4025/actascianimsci.v37i4.28051.

SBRISSIA, A. F.; DA SILVA, S. C. Tiller size/density compensation in Marandu palisadegrass swards. Revista Brasileira de Zootecnia, v.37, n.1, p.35-47, jan. 2008. Available from: $\quad<$ http://www.scielo.br/scielo.php?script=sci arttext\&pid $=$ S1516-35982008000100005>. Accessed: Oct. 18, 2019. doi: 10.1590/S1516-35982008000100005.

SCHNYDER, H.; et al. An integrated view of $\mathrm{C}$ and $\mathrm{N}$ uses in leaf growth zones of defoliated grasses. In: LEMAIRE, G.; et al. Grassland ecophysiology and grazing ecology, Oxford: CABI International, 2000. Cap.3, p.41-60.

STEINFELD, H.; et al. Livestock's long shadow: Environmental issues and options. Rome: Food and Agriculture Organization of the United Nations (FAO), 2006, 1 ed.

STIVANIN, S. C. B. et al. Ingestive behavior of hoggets given different types of supplement on ryegrass pasture. ACTA, v.36, n.1, p.101-107, jan/mar. 2014. Available from: <http://www.scielo.br/ scielo.php?script=sci_arttext\&pid=S1807-86722014000100014 $>$. Accessed: Sep. 21, 2019. doi: 10.4025/actascianimsci.v36i1.21641.

TAIZ, L.; et al. Plant senescence and cell death. p. 665-692. In: Plant Physiology and Development, Oxford: Oxford University Press, 2017. Cap.22, p.665-692.

TRACY, B. F. et al. Conditions that favor clover establishment in permanent grass swards. Japanese Society of Grassland Science, Grassland Science v.61: p.34-40, Oct. 2014. Available from: $<$ https://onlinelibrary.wiley.com/doi/full/10.1111/grs.12075>. Accessed: Sep. 21, 2019. doi: 10.1111/grs.12075.

TRACY, B. F.; et al. Effects of plant diversity on invasion of weed species in experimental pasture communities. Basic and Applied Ecology. v.5; p.543-550, 2004. Available from: $<$ https:// www.sciencedirect.com/science/article/pii/S1439179104000672>. Accessed: Sep. 21, 2019. doi: 10.1016/j.baae.2004.08.007. 